\title{
Characterization of the Nigerian Population of the Reniform nematode, Rotylenchulus reniformis based on the Analysis of the $28 \mathrm{~S}$ Ribosomal RNA
}

\author{
Fisayo Y. Daramola and Francis Lewu
}

\begin{abstract}
The reniform nematode, Rotylenchulus reniformis is an important nematode pest of agricultural crops. A Nigerian population of $R$. reniformis associated with cassava (manihot esculenta) was characterized using a combination of morphological and molecular tools. Molecular features of the nematode were similar to the type population of $R$. reniformis. Life stages of the nematode were isolated from soil and DNA was extracted from single young female nematodes for molecular identification and phylogenetic studies. Analysis of the partial sequences of the $28 \mathrm{~S}$ rRNA segment of the obtained sequence revealed a strong affinity of $98.87 \%$ similarity to previously published sequences of $R$. reniformis from China. Phylogenetic analyses with Maximum Parsimony and Neighbour Joining methods indicated that the Nigerian isolate of $R$. reniformis corresponded to the previously described species. The molecular phylogeny by using the $28 \mathrm{~S}$ expansion region confirms the presence of $R$. reniformis in Nigeria soils.
\end{abstract}

Keywords - plant-parasitic nematodes, polymerase chain reaction, Rotylenchulus reniformis, $28 \mathrm{~S}$ ribosomal RNA.

\section{INTRODUCTION}

The reniforn nematode, Rotylenchulus reniformis (Linford \& Oliveira 1940) has emerged as an important pest of many plants in the subtropical, tropical and warm-temperate regions of the world [1]. They are frequently encountered and abundant in the soil as sedentary semi-endoparasites and are serious pests of crops such as soybean, cowpea, cotton, pineapple, sweet potato, cassava and some vegetable crops. [2] - [3]. An estimated yield loss of about $\$ 90$ million [4] was reported on cotton in the United States due to damage by the reniform nematodes.

The life cycle of $R$. reniformis is one of the adaptive features that make them exhibit great damaging potential on agricultural crops and enable them to survive under adverse environmental conditions, even in the absence of a host [1]. It consists of a juvenile stage, which is enclosed within the egg and undergoes a

Manuscript received October 20, 2020.

Fisayo Daramola is a Post-Doctoral Fellow at the Department of Agricultural Science, Cape Peninsula University of Technology, Wellington Campus, Cape Town, South Africa..

Francis Lewu is a Professor of Botany. He is the head of Department of Agricultural Sciences, Faculty of Applied Sciences Cape Peninsula University of Technology, Wellington Campus, Cape Town, South Africa. moult to produce the second stage juvenile (J2), emerging from the egg with strong mobility and conspicuous stylet. The J2 eventually becomes less active and moults to the non-feeding 3rd stage juvenile (J3) which assumes a crescent shape, and is often characterized by the presence of the $\mathrm{J} 2$ cuticle, lack of movement and the absence of a stylet [3]. Further morphological changes and moulting leads to the development of the fourth stage juvenile (J4) and then emerges the male and female actively feeding infective stage that is usually commonly found in the soil. The vermiform infective female $R$. reniformis infects the host root tissue, feeds with the formation of syncytium, becomes sedentary and eventually attains a characteristic kidney shape. The vermiform males do not feed but are abundant in the soil fertilizing the females.

About 11 valid species of nematodes belonging to the genus Rotylenchulus have been identified [5] but the most common of this group is $R$. reniformis. In Nigeria, reports of the association of $R$. reniformis with economic crops such as cashew (Anacardium occidentale L), pineapple (Ananas comosus Meer), sugarcane (Saccharum officinarum L.), sweet potato (Ipomoea batatas L. Lam) and cassava (Manihot esculenta Crantz) have been documented [6] - [8]. These studies suggest that the reniform nematode is common and abundant in many agricultural soils in Nigeria, however, molecular identification of the nematode species is yet to be done and to the best of our knowledge, no reference molecular data of this important nematode specie is available in Nigeria.

In this study, $R$. reniformis was isolated from an arable farmland in Nigeria and was identified using molecular tools based on the analysis of the $28 \mathrm{~S}$ ribosomal gene. The first molecular data of the Nigerian population of the reniform nematode is thus, provided in this study.

\section{MethodOLOGY}

\section{A. Nematode Isolation and Morphological Identification}

Soil samples were collected from the rhizosphere of cassava from the teaching and research farm of Landmark University in Nigeria, located at $8.1248630 \mathrm{NE}, 5.0764680 \mathrm{SW}$ and $143 \mathrm{~m}$ a.s.l. Nematodes were isolated from soil samples and life stages were of the reniform nematode were collected using a modified 
method [3]. Nematodes were observed under a compound microscope and identified to the genus using the diagnostic features in "A pictorial key to genera of plant-parasitic nematodes" [9], as a guide. Photomicrographs of life stages were taken with the aid of a Zeiss Axioskop 40 compound microscope.

\section{B. DNA Extraction and PCR Based Molecular Identification}

DNA was extracted from the young female life stage, a procedure that was carried out under a stereo-microscope. Single females were aseptically picked, cut into about 2-3 parts using sterile needles and placed in Eppendorf tubes containing $10 \mu 1$ of lysis buffer. The tubes were placed in a $-80^{\circ}$ freezer for a minimum of $15 \mathrm{~min}$ and then incubated at $65^{\circ} \mathrm{C}$ for $60 \mathrm{~min}$ and $95^{\circ} \mathrm{C}$ for $15 \min [10]$.

Polymerase chain reaction for the amplification of the D2D3 expansion segment of the $28 \mathrm{~S}$ fragment of the ribonucleic DNA was done in a thermocycler using KAPA2 $\mathrm{G}^{\mathrm{TM}}$ Robust Hotstart ReadyMix (KAPA Biosystems) and the primer set of a forward primer D2A (ACA AGT ACC GTG AGG GAA AGT TG) and reverse primer D3B (TCG GAA GGA ACC AGC TAC TA). The cycling condition was $94^{\circ} \mathrm{C}$ for $2 \mathrm{~min}$, followed by 35 cycles of denaturation at $94^{\circ} \mathrm{C}$ for $30 \mathrm{sec}$, annealing at $57^{\circ} \mathrm{C}$ for $45 \mathrm{sec}$ and extension at $72^{\circ} \mathrm{C}$ for 3 min with a final extension at $72^{\circ} \mathrm{C}$ for $10 \mathrm{~min}$. The DNA fragments were separated on $1.5 \%$ agarose gel, which was stained with ethidium bromide. The PCR products were visualised under UV light with a transilluminator imaging system.

\section{Sequence and Phylogenetic Analyses}

Purification of the PCR products was performed using the NucleoFast Purification Method (Macherey Nagel, Waltham, Massachusetts, USA). Sequencing of the DNA was performed in both directions with the Big Dye Terminator V1.3 sequencing kit, followed by the use of electrophoresis on the $3730 \mathrm{X}$ 1DNA Analyser (Applied Biosystems) at the DNA Sequencing Unit (Central Analytical Facilities, Stellenbosch University). For manual sequence assembly and editing, the software for biological sequence alignment editor, Bioedit 7.2 [11] was used and the newly obtained DNA sequence was deposited at the National Centre for Biotechnology Information (NCBI) with the accession number MW130089.

The newly acquired DNA sequence was compared with GenBank sequences by BLASTN. Available DNA sequences of Rotylenchulus reniformis on the NCBI were downloaded and aligned with the newly obtained sequence from Nigeria with the Multiple alignment program for amino acid or nucleotide sequences, MAFFT version 7 [12]. The evolutionary history was inferred using the Maximum Parsimony (MP) and Neighbour Joining (NJ) methods. Evolutionary analyses were conducted in MEGA X [13] and the confidence intervals for the various branching patterns in the trees was measured using bootstraps with 1000 replicates..

\section{RESULT}

\section{A. Morpho-Molecular Identification}

The Nigerian population of Rotylenchus reniformis identified in this study is similar morphologically with the type population. The diagnostic characters and morphological features are characteristic of $R$. reniformis (Fig. 1). The habitus shape is $\mathrm{C}$ and the head region of the young female is not offset with prominent cephalic structure. The length of stylet is about 17 to $20 \mu \mathrm{m}$ long, with small rounded knobs. Dorsal oesophageal gland orifice is more than $1 \frac{1 / 2}{2}$ of the stylet length. The vulva is post-median, positioned at about $63 \%$ of the body length. The reproductive system is amphidelphic with two flexures in immature females and the tail is more than twice the length of the anal body diameter. Males have weak stylets and indistinct median bulb and valve. The caudal alae are adanal. The morphological features of a young female $R$. reniformis and the gel image of the PCR product obtained from the nematode is shown in Fig. 2.

\section{B. Phylogenetic Analysis}

From the DNA sequence analysis, alignments of the $28 \mathrm{~S}$ rRNA sequence of the newly obtained sequences of $R$. reniformis showed high similarity to the sequences of the nematode that were available on the NCBI database from China, Colombia, Florida, Paragua and Brazil. The Nigerian isolate was close to that obtained from china with a similarity of 98.87\%. Phylogenetic relationships within the genus Rotylenchulus as inferred from maximum parsimony (MP) and Neighbour joining (NJ) is given in Fig. 3 and 4 respectively. The sequence alignment was 764 base pairs long and comprised of 25 nucleotide sequences of Rotylenchulus spp with Hoplolaimus seinhorsti as the outgroup.

Both MP and ML phylogenetic trees show a congruence in the position of the Nigerian isolate, which clustered with sequences of $R$. reniformis from other countries [14].

\section{DISCUSSION}

Rotylenchulus reniformis is one of the most important plant-parasitic nematodes of economic importance [15]. Heavy economic losses [3], [4] have been reported due to damage caused by the feeding activities of the reniform nematode on agricultural crops. About 11 species in the genus Rotylenchulus have been identified [5]. The known species include; $R$. borealis, $R$. clavicaudatus, $R$. eximius, $R$. leptus, $R$. macrodoratus, $R$. macrosoma, $R$. macrosomoides, $R$. parvus, $R$. reniformis, $R$. sacchari, and $R$. vitis. In the current study, the combination of molecular tools with the morphological characters confirmed the identity and prevalence of the $R$. reniformis from Nigerian soil.

The result of the phylogenetic analysis corresponds and is consistent with previous studies [5], [14] and provides a baseline information on molecular data of the Nigerian population of $R$. reniformis. Although the reniform nematode have been frequently encountered in many agricultural soils in Nigeria [6] - [8], accurate identification of the specie causing damage is yet to be established, due to the limitations in resources for molecular characterization. Identification of most Nigerian nematode species are based on traditional morphological features, a practice which has been criticized in recent times as being time consuming, difficult and often require 
skilled personnel [16]. Morphological identification is also limited in use, especially when differentiating between cryptic nematode species due to high intraspecific variability and overlapping of some diagnostic features.

\section{CONCLUSION}

Accurate and precise identification of important nematode species is a prerequisite for effective management options and is quintessential for designing good quarantine and phytosanitary programmes. Molecular based tools in combination with morphological identification is therefore, recommended in order to effectively discriminate between the cryptic species and ensure accurate diagnosis of nematode species of economic importance.
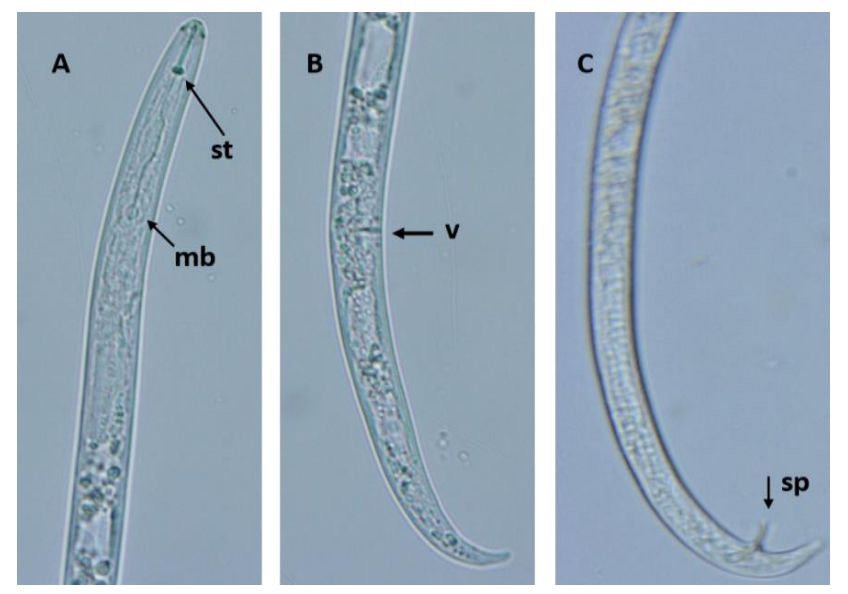

Fig. 1. Photomicrograph of Rotylenchulus reniformis a. Head region $\mathrm{b}$. female tail c. male tale. $\mathrm{mb}=$ median bulb, $\mathrm{v}=$ vulva, $\mathrm{sp}=$ spicule $($ Scale bar $=50 \mu \mathrm{m})$.
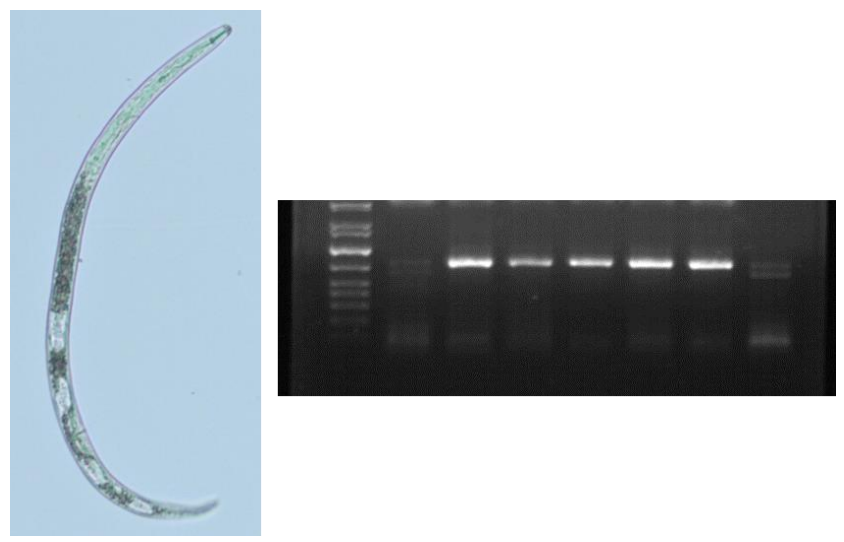

Fig. 2. Photomicrograph of a single young female Rotylenchulus reniformis and the PCR product obtained from molecular identification of the nematode.

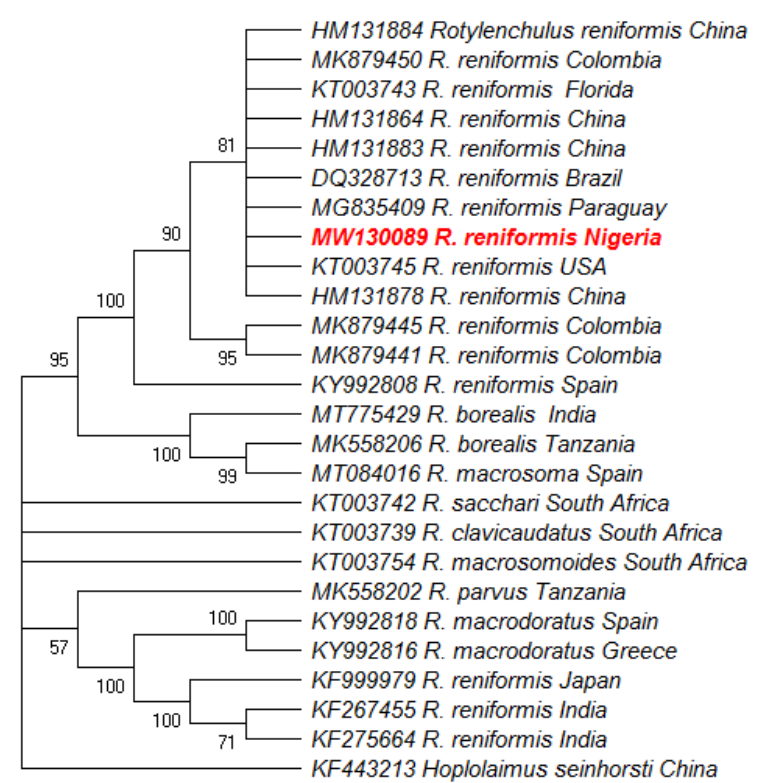

Fig. 3. Phylogenetic relationships within Rotylenchulus species, based on analysis of the D2D3 regions with Maximum Parsimony (MP) method, using Hoplolaimus seinhorsti as the outgroup. Newly obtained Nigerian isolate is highlighted.

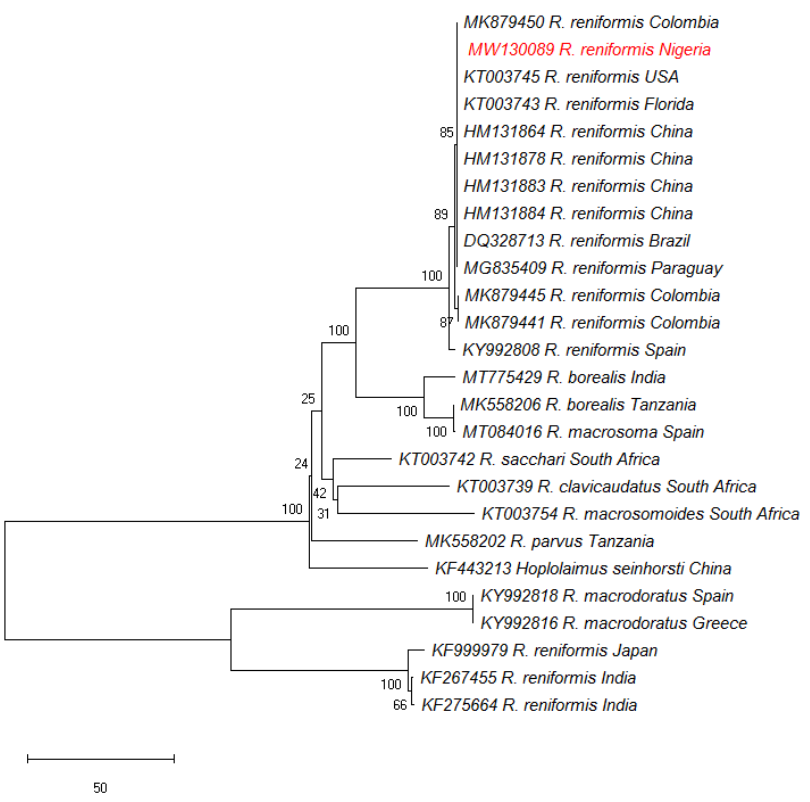

Fig. 4. Phylogenetic relationships within Rotylenchulus species, based on analysis of the D2D3 regions with Neighbour Joining (NJ) method, using Hoplolaimus seinhorsti as the outgroup. Newly obtained Nigerian isolate is highlighted.

\section{REFERENCES}

[1] A.F. Robinson, R.N Inserra, E. P. Caswell-Chen, N. Vovlas, and A. Troccoli, "Rotylenchulus species: Identification, distribution, host ranges and crop plant resistance," Nematropica, vol 27, pp. 127-180, Dec. 1997.

[2] H. S. Gaur, and R. N. Perry, "The biology and control of the plant parasitic nematode Rotylenchulus reniformis," Agricultural Zoology Reviews, vol 4, pp.177-212, 1991. 
[3] S. Ganji, M. J. Wubben, and J. N. Jenkins, "Two simple methods for the collection of individual life stages of reniform nematode, Rotylenchulus reniformis," J. Nematol. vol 45, pp. 87-91, June. 2013.

[4] D. Blasingame, and M. V. Patel, "Cotton disease loss estimate committee report." in Proceedings of the Beltwide Cotton Conference, Orlando, FL, Memphis, TN: National Cotton Council of America, 2012 pp. 341-343.

[5] E. Van den Berg, J. Palomares-Rius, N. Vovlas, L. Tiedt, P. Castillo, P. and S. Subbotin, "Morphological and molecular characterisation of one new and several known species of the reniform nematode, Rotylenchulus Linford \& Oliveira, 1940 (Hoplolaimidae: Rotylenchulinae), and a phylogeny of the genus," Nematology, vol. 18, pp. 67-107. Jan. 2016. https://doi.org/10.1163/15685411-00002945

[6] S. B. Orisajo, "Distribution and effect of plant-parasitic nematodes associated with cashew in North Central-Nigeria," Agricultural Journal, vol. 7, pp. 405-40, 2012.

https://doi.org/10.3923/aj.2012.405.407

[7] F.Y. Daramola, S. O. Afolami, A. A, Idowu and E.I. Nwanguma, "Studies on the occurrence and distribution of plant-parasitic nematodes in some pineapple-producing states in Nigeria," Asian Journal of Crop Science, vol. 5, pp. 190-199, May. 2013 https://doi.org/10.3923/ajcs.2013.190.199

[8] I. O. Olabiyi, O. A. Fabiyi, J. J Atungwu and I. O. Adepoju, "Plant parasitic nematode associated with sweet potato in Nigeria," American Journal of Agricultural Research, vol. 1(5), pp. 0032-0038, 2016.

[9] W. F. Mai, and P. G. Mullin, Plant parasitic nematode. A pictorial key to genera, 5th ed. Cornell University Press, Ithaca, New York, USA. 1996 https://doi.org/10.7591/9781501728419

[10] F. Y. Daramola, R. Knoetze, A. Swart, and A. P. Malan "First report and molecular characterization of the dagger nematode, Xiphinema oxycaudatum (Nematoda, Dorylaimidae) from South Africa," ZooKeys vol. 894 , pp. 1-17, Dec. 2019 https://doi.org/10.3897/zookeys.894.35281

[11] T. A. Hall, "BioEdit: a user-friendly biological sequence alignment editor and analysis program for windows 95/98/NT," Nucleic Acids Symposium Series, vol. 41, pp. 95-98 1999.

[12] K. Katoh K. and D. M. Standley, "MAFFT multiple sequence alignment software version 7: improvements in performance and usability," Molecular Biology and Evolution, vol. 30, (4), pp. 772-780, April. 2013 https://doi.org/10.1093/molbev/mst010

[13] S. Kumar, G. Stecher, M. Li, C. Knyaz, and K. Tamura, "MEGA X: Molecular Evolutionary Genetics Analysis across computing platforms," Molecular Biology and Evolution, vol. 35, pp. 1547-1549, June. 2018. https://doi.org/10.1093/molbev/msy096

[14] D. Riascos-Ortiz, A. T. Mosquera-Espinosa, F. Varón de Agudelo, C. M. G. Oliveira, and J. E. de, Omuñoz-Flórez, " Morpho-molecular characterization of Colombian and Brazilian populations of Rotylenchulus associated with Musa spp," Journal of Nematology, vol. 51, pp. 1-13, Jan. 2019

https://doi.org/10.21307/jofnem-2019-047

[15] J. T. Jones, A. Haegeman, E. G. J. Danchin, H. S. Gaur, J. Helder, M. G. K. Jones, T. Kikuchi et al. "Top 10 plant-parasitic nematodes in molecular plant pathology," Molecular Plant Pathology, vol 14 (9), pp. 946-961. https://doi.org/10.1111/mpp.12057

[16] S. A. Subbotin, D. Sturhan, H. J. Rumpenhorst, and M. Moens. "Molecular and morphological characterisation of the Heterodera avenae species complex (Tylenchida:Heteroderidae)," Nematology, vol. 5 pp. 515-538, Jan. 2003. https://doi.org/10.1163/156854103322683247

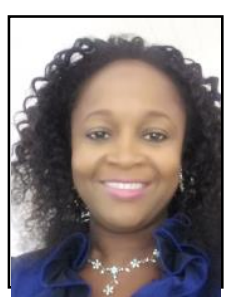

Fisayo Y. Daramola is a Nigerian by birth and holds a South African permanent residency. She has an academic background of a Bachelor's degree (B.Sc.) in agricultural science, Master's degree (MSc) in crop protection and a Ph.D. in plant nematology from Nigerian Universities.

She has about nine years of teaching and research experience in the University environment. Dr. Daramola was a postdoctoral fellow at the Department of Conservation Ecology \& Entomology, Stellenbosch University (2016-2019) and currently with the Department of Agricultural Sciences, Cape Peninsula University, South Africa. She has presented her research outputs in both international and local conferences and published in some peer-reviewed DHET accredited journals. She is concerned about nematode pests of agricultural crops and their damaging effects on plant health and the environment.

Dr. Daramola was a recipient of the TWAS/NRF Post-Doctoral Fellowship; NUFFIC scholarship for Food Safety \& Integrated Pest Management (IPM) at Wageningin University, Netherlands. She was also a recipient of the African Collaboration Grant (ACG) by Stellenbosch University. She has made great contribution to diagnosis and management of nematode pests and has reported some new species of important plant parasitic and entomopathogenic nematodes from Nigeria and South Africa. 